\title{
Novel regulatory therapies for prevention of Graft-versus-host disease
}

\author{
Joseph Leventhal ${ }^{1}$, Yiming Huang ${ }^{2}$, Hong $X^{2}{ }^{2}$, Idona Goode ${ }^{2}$ and Suzanne T Ildstad ${ }^{2 *}$
}

\begin{abstract}
Graft-versus-host disease is one of the major transplant-related complications in allogeneic hematopoietic stem cell transplantation. Continued efforts have been made to prevent the occurrence of severe graft-versus-host disease by eliminating or suppressing donor-derived effector $T$ cells. Conventional immunosuppression does not adequately prevent graft-versus-host disease, especially in mismatched transplants. Unfortunately, elimination of donor-derived T cells impairs stem cell engraftment, and delays immunologic reconstitution, rendering the recipient susceptible to post-transplant infections and disease relapse, with potentially lethal consequences. In this review, we discuss the role of dynamic immune regulation in controlling graftversus-host disease, and how cell-based therapies are being developed using regulatory $T$ cells and other tolerogenic cells for the prevention and treatment of graft-versus-host disease. In addition, advances in the design of cytoreductive conditioning regimens to selectively target graft-versus-host disease-inducing donor-derived T cells that have improved the safety of allogeneic stem cell transplantation are reviewed. Finally, we discuss advances in our understanding of the tolerogenic facilitating cell population, a phenotypically and functionally distinct population of bone marrow-derived cells which promote hematopoietic stem cell engraftment while reducing the risk of graft-versus-host disease.
\end{abstract}

\section{Review}

Regulatory T cells in graft-versus-host disease-prevention Graft-versus-host disease (GVHD) remains a major obstacle for the clinical application of hematopoietic stem cell (HSC) transplantation [1]. GVHD is initiated by

\footnotetext{
* Correspondence: suzanne.ildstad@louisville.edu

${ }^{2}$ Institute for Cellular Therapeutics, University of Louisville, Louisville, KY, USA Full list of author information is available at the end of the article
}

alloreactive donor $\mathrm{T}$ cells which recognize the host minor and major histocompatibility (MHC) antigens, proliferate, and damage target tissues. Donor T cells have been shown to enhance engraftment of HSC, reconstitute T cell immunity, and mediate a potent beneficial anti-tumor effect, known as graft-versus-leukemia (GVL) effect. Depletion of donor T cells impairs engraftment of HSC and abrogates the $\mathrm{T}$ cell-mediated GVL effect. In addition, administration of immunosuppressive drugs to prevent GVHD after HSC transplantation impairs $\mathrm{T}$ cell function and increases the risk of opportunistic infection and tumor relapse. Therefore, recent approaches have focused on tailored approaches to maintain the desirable effect of GVL yet avoid GVHD after HSC transplantation. Recent preclinical novel cell-based therapies have been developed to achieve these outcomes. They are currently being translated to the clinic.

The mechanisms of donor $\mathrm{T}$ cell $\left(\mathrm{CD}^{+} \mathrm{T}\right.$ cell and $\mathrm{CD}^{+} \mathrm{T}$ cell)-mediated GVHD are multifactorial and include activation of macrophages and antigen-presenting cells (APC) by transplantation conditioning regimens to damage host tissue, releasing soluble cytokines such as TNF- $\alpha$ and IL-1; alloreactive T cell activation, proliferation and differentiation in response to host or donor APC; and alloreactive $\mathrm{T}$ cell infiltration and release of pro-inflammatory cytokines which leads to damage of the target tissue [2]. Over the past two decades, the importance of regulatory populations of lymphocytes in controlling immune responses has been increasingly appreciated. Although different cell subsets with regulatory activity have been described, including $\mathrm{CD} 4^{+} / \mathrm{CD} 25$ ${ }^{+} /$forkhead/winged helix transcription factor ${ }^{+}\left(\mathrm{FoxP}^{+}\right)$, $\mathrm{CD}^{+} / \mathrm{CD}^{2} 8^{-}, \mathrm{T} /$ natural killer $(\mathrm{NK})$ cells, and TCR ${ }^{+} / \mathrm{CD} 4^{-} / \mathrm{CD}^{-}$, most studies have concentrated on CD4 ${ }^{+} / \mathrm{CD} 25^{+} / \mathrm{FoxP}^{+} \mathrm{T}$ cells [3]. Among the $\mathrm{CD}^{+}{ }^{+} \mathrm{T}$ cell population, $\mathrm{CD} 4^{+} / \mathrm{CD} 25^{+} / \mathrm{FoxP}^{+}$regulatory $\mathrm{T}$ cells $\left(\mathrm{T}_{\text {reg }}\right)$ have been demonstrated to suppress a variety of immune responses dependent on effector $\mathrm{T}$ cells.

$\mathrm{CD}^{+} \mathrm{T}_{\text {reg }}$ have been divided into two major groups: the naturally occurring $\mathrm{T}_{\text {reg }}$ and inducible $\mathrm{T}_{\text {reg }}$. Both
C Biomed Central

() 2012 Leventhal et al; licensee BioMed Central Ltd. This is an Open Access article distributed under the terms of the Creative Commons Attribution License (http://creativecommons.org/licenses/by/2.0), which permits unrestricted use, distribution, and reproduction in any medium, provided the original work is properly cited. 
types of $T_{\text {reg }}$ have proven effective in preventing GVHD in murine models of GVHD $[4,5]$ and, to a lesser extent, in human HSC transplantation [6-8]. Although studies have suggested that $\mathrm{T}_{\text {reg }}$ downregulate both $\mathrm{T}$ helper 1and $\mathrm{T}$ helper 2-mediated immune responses, mainly through IL-10 and transforming growth factor beta (TGF- $\beta$ ) production, direct cell-cell contact has also been postulated to be required as a mechanism of action. Natural $\mathrm{T}_{\text {reg }}$ are generated in the thymus and are nonspecific in their suppressive capability [3,9]. Although natural $\mathrm{T}_{\text {reg }}$ must encounter antigens to exert their suppressive effects, once activated they suppress in an antigen-nonspecific manner, presumably through the release of immunosuppressive cytokines such as IL-10 and TGF- $\beta$ [10]. Because of their nonspecific mechanism of action, there is concern regarding their clinical relevance. Importantly, antigen-specific $\mathrm{T}_{\text {reg }}$ are inducible and need to be activated through their TCR in order to mediate their suppressive activities. The expression of receptors of chemokines, such as $\mathrm{C}-\mathrm{C}$ chemokine receptor type 5 (CCR5) and CXC chemokine receptor 3 (CXCR3), on antigen-specific $\mathrm{T}_{\text {reg }}$ support a role for proper trafficking of $\mathrm{T}_{\text {reg }}$ to target tissue in the prevention of acute GVHD in murine models [11,12]. A recent study showed that tolerant patients without GVHD after HSC transplantation expressed significantly higher levels of CCR5 and CXCR3 compared with patients with acute GVHD early after HSC transplantation [8], suggesting that homing of $\mathrm{T}_{\text {reg }}$ to secondary lymphoid tissues and sites of inflammation may play an important role in the control of GVHD.

Several studies in experimental murine models have shown that $\mathrm{T}_{\text {reg }}$ can suppress proliferative activity of conventional $\mathrm{CD}^{+}{ }^{+} \mathrm{T}$ cells and $\mathrm{CD}^{+}{ }^{+} \mathrm{T}$ cells to alloantigenic stimulation in vitro and induce transplantation tolerance and reduce acute GVHD occurrence in vivo [13-15]. Donor $C D 4^{+} / \mathrm{CD} 25^{+} \mathrm{T}_{\text {reg }}$ isolated from the spleen or bone marrow of C57BL/6 mice can suppress lethal GVHD induced by transplanted donor CD4 ${ }^{+} / \mathrm{CD} 25^{-} \mathrm{T}$ effector cells after allogeneic $\mathrm{T}$ cell-depleted bone marrow transplantation (BMT) [14]. Importantly, the beneficial effect of adoptively transferred CD4 ${ }^{+} / \mathrm{CD} 25^{+} \mathrm{T}_{\text {reg }}$ does not abrogate the beneficial effect of donor T cell-mediated GVL [13]. Ianni et al. recently evaluated the impact of early infusion of freshly isolated human donor $\mathrm{CD} 4^{+} / \mathrm{CD} 25^{+} \mathrm{T}_{\text {reg }}$ followed by conventional $\mathrm{T}$ cells in human leukocyte antigen (HLA)-haploidentical HSC transplantation [16]. Adoptive transfer of human donor $\mathrm{T}_{\text {reg }}$ prevented acute as well as chronic GVHD in the absence of immunosuppressive drug therapy after transplantation. Moreover, $\mathrm{T}_{\text {reg }}$ promoted immune reconstitution of $\mathrm{CD} 4^{+} \mathrm{T}$ cells, $\mathrm{CD} 8^{+} \mathrm{T}$ cells, $\mathrm{B}$ cells, and NK cells, and improved protective immunity against cytomegalovirus infection.
The major limitation for the clinical application of

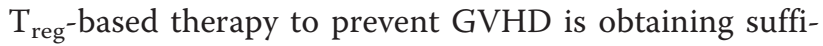
cient numbers of antigen-specific $T_{\text {reg }}$ and maintaining their regulatory properties after infusion [17]. Studies showed that ex vivo expansion of mouse recipient-specific $\mathrm{CD} 4^{+} / \mathrm{CD} 25^{+} \mathrm{T}_{\text {reg }}$ can be obtained using donor $\mathrm{T}_{\text {reg }}$ stimulation with allogeneic recipient APC $[18,19]$. Ex vivo expansion of $\mathrm{T}_{\text {reg }}$ resulted in specific tolerance for recipient-type alloantigens, but not for third-party antigens. Moreover, the $\mathrm{T}_{\text {reg }}$ effectively controlled GVHD while favoring immune reconstitution and maintaining GVL in a murine model [18]. Another study showed that rapamycin-induced $\mathrm{T}_{\text {reg }}$ from human $\mathrm{CD} 4^{+} / \mathrm{CD} 25^{-} /$ CD45RA ${ }^{+}$cells exhibit a potent suppressive function in vitro compared with natural $\mathrm{T}_{\text {reg, }}$, and suppress acute GVHD in a xenogeneic NOD/SCID mouse model [20]. Clinical trials of therapeutic cell transfer using $\mathrm{T}_{\text {reg }}$ for the prevention and/or treatment of GVHD have recently been described. Ianni et al. reported that the adoptive transfer of freshly isolated, donor-derived natural $\mathrm{T}_{\text {reg }}$ followed by conventional donor-derived $\mathrm{T}$ cells (Tcon) at the time of full-haplotype-mismatched adult HSC transplantation in patients being treated for hematologic malignancies prevented acute or chronic GVHD while favoring Tcon-mediated post-transplantation immune reconstitution [16]. Brunstein et al. detailed a 'first-inhuman' phase 1 clinical trial of nonspecific (CD3/CD28 bead)-based ex vivo expanded umbilical cord bloodderived $\mathrm{T}_{\text {reg }}$ in patients after umbilical cord blood transplantation and noted a reduced incidence of severe acute GVHD [21].

$\mathrm{T}_{\text {reg }}$ as diagnostic and prognostic cellular biomarkers for acute GVHD have been investigated in mouse and rat models and human HSC transplantation [22-25]. Studies reported that the level of FoxP3 mRNA expression in peripheral blood mononuclear cells from patients with either acute GVHD or chronic GVHD was significantly decreased compared with patients without GVHD $[25,26]$, suggesting that a regulatory mechanism is involved in the development of GVHD. The number of FoxP3 ${ }^{+} \mathrm{T}_{\text {reg }}$ in skin biopsies from GVHD patients was significantly higher in patients responding to GVHD treatment and with a lower grade of GVHD compared with those with more severe GVHD [23]. Taken together, these observations indicate that $\mathrm{T}_{\text {reg }}$ can regulate immune responses and induce tolerance to alloantigen after HSC transplantation. These findings provide evidence for the use of $\mathrm{T}_{\text {reg }}$ as a useful biologic to improve GVHD diagnosis and treatment.

\section{Cyclophosphamide and prevention of graft-versus-host disease}

In GVHD, functional immune cells in the donor bone marrow recognize the recipient as foreign and mount an 
immunologic attack on the patient's organs and tissues, impairing their ability to function [1]. Strict HLA matching between donors and transplant patients has been proven to reduce the incidence and severity of GVHD [27]. However, approximately $50 \%$ of patients still develop GVHD even if they undergo allogeneic HSC transplantation with HLA-matched donors [28]. The challenge facing HSC transplantation is to achieve better allogeneic engraftment without graft rejection and GVHD. The common reagents of GVHD prophylaxis comprise cyclosporine, or tacrolimus, methotrexate, mycophenolic acid, or sirolimus [29-31]. However, cyclophosphamide has been found more recently in animal and clinical studies to be a better and potent prophylactic agent of GVHD without obvious aplasia due to toxicity to donor stem cells [32-36]. When it is used in high dose after allogeneic BMT in mouse models, cyclophosphamide targets alloreactive proliferating $\mathrm{T}$ cells and enhances alloengraftment without causing GVHD [32-34]. Therefore, in order to gain the effect of cyclophosphamide in enhancing alloengraftment, it has to be used 48 hours after BMC infusion but not before [32]. High-dose cyclophosphamide given on day 2 after transplantation mitigated both the incidence and severity of acute GVHD in an MHC-mismatched donor-recipient combination [37]. The effect of post-transplantation cyclophosphamide in GVHD prevention has been demonstrated by inhibiting graft-versus-host reactions and selectively eliminating activated $\mathrm{T}$ cells in response to donor antigens in minor histocompatibility disparity [38] and MHC-mismatched [33] mouse models. Clinically, post-transplantation cyclophosphamide has reduced the incidence and severity of GVHD across MHC barriers after BMT [33-35,39,40]. High expression of aldehyde dehydrogenase in HSC allows for the prompt inactivation of cyclophosphamide and helps explains their relative resistance to the effects of this alkylating agent. In contrast, activated lymphocytes express low levels of aldehyde dehydrogenase and are particularly susceptible to cyclophosphamide. Importantly, these preclinical studies demonstrated the specific safety profile of cyclophosphamide in stem cell-sparing activity, thus provided the preclinical rationale to proceed with a clinical trial of partially HLA-mismatched or HLA-haploidentical BMT with high-dose post-transplantation cyclophosphamide for patients with poor prognosis hematologic malignancies.

The major clinical rationale for HLA-haploidentical BMT is to extend the potential benefits of HSC transplantation and the graft-versus-tumor effect to patients who lack an HLA-matched donor. The major challenge is to reduce the incidence of fatal graft rejection, severe GVHD and treatment-related mortality while promoting engraftment. Luznik et al. recently reported the outcomes of 68 patients with poor-risk hematologic malignancies who were conditioned with fludarabine, cyclophosphamide and 2 Gy total body irradiation prior to receiving $\mathrm{T}$ cell-replete bone marrow from HLA-haploidentical, first-degree relatives [36]. Donors and recipients were mismatched at a median of four out of five HLA alleles, indicating substantial donor-recipient histoincompatibility. GVHD prophylaxis comprised intravenous cyclophosphamide $50 \mathrm{mg} / \mathrm{kg}$ on day $3(\mathrm{n}=28)$ or on days 3 and $4(n=40)$ after transplantation, followed by tacrolimus and, mycophenolic acid. These two drugs were included to provide extra protection against graft failure and GVHD. They were started after the completion of cyclophosphamide in light of preclinical data indicating that calcineurin inhibitors block cyclophosphamide-induced transplantation tolerance by blocking the activation and proliferation of alloreactive $\mathrm{T}$ cells [41]. Recovery of neutrophils and platelets occurred at a median of 15 and 24 days, respectively, after transplantation. Graft failure occurred in nine patients (13\%). Acute grades II to IV occurred in $34 \%$ and III to IV GVHD in 6\% of patients, and chronic GVHD developed in $15 \%$ of patients. These rates of GVHD development are comparable to or below the incidences of acute and chronic GVHD after HLA-matched HSC transplantation without post-transplantation cyclophosphamide [42]. One year after transplantation, the cumulative incidence of relapse mortality was $51 \%$ and non-relapse mortality was $15 \%$, and overall survival and event-free survival at 2 years after transplantation were $36 \%$ and $26 \%$, respectively. Only six patients died, four of infection and two of GVHD. These data support the safety and potential efficacy of post-transplantation cyclophosphamide in preventing GVHD and fatal graft rejection after HLAhaploidentical HSC transplantation.

Based upon the results of Luznik and Fuchs [35,36,39], we have included the use of post-transplant cyclophosphamide $(50 \mathrm{mg} / \mathrm{kg}$ day, 3 days after BMT) as part of a non-myeloablative conditioning regimen being used in an ongoing phase 2 trial of tolerance induction in recipients of mismatched kidney and stem cell transplants. Durable donor chimerism has been achieved in five of the first eight participants and no patient has developed GVHD [43].

\section{The facilitating cell: a key regulator of stem cell engraftment}

$\mathrm{T}$ cell depletion (TCD) of allogeneic bone marrow is extremely effective at reducing the risk of GVHD, but greatly increases the risk of engraftment failure. Three possible reasons for TCD-associated-engraftment failure have been hypothesized. First, HSC can engraft across MHC-matched but minor disparate barriers, but fail to engraft in allogeneic recipients because they are harmed 
or removed during TCD. Second, T cells act as essential partner cells to promote allogeneic HSC engraftment. Third, an additional bone marrow population that shares some $\mathrm{T}$ cell markers protects the HSC from rejection or 'facilitates' HSC engraftment, but is inadvertently removed as an 'innocent bystander' during TCD. Investigations in different laboratories have provided strong evidence in support of the latter hypothesis. Initial studies in mice using different cell subsets sorted from donor bone marrow identified a distinct population of $\mathrm{CD}^{+} / \mathrm{TCR}^{-}$facilitating cells (FC) capable of promoting allogeneic HSC engraftment and establishment of mixed chimerism [44]. The addition of 30,000 MHCmatched purified FC to as few as 10,000 donor HSC into ablated MHC-disparate B10 recipients resulted in stable allogeneic engraftment across both class I and class II barriers, without causing GVHD [44]. Transplantation of FC alone failed to rescue recipients, indicating that FC are not an HSC. Importantly, FC + HSC reconstituted animals exhibit donor-specific tolerance for skin, cardiac and islet grafts.

In light of the fact that FC function is distinct from that demonstrated by bone-marrow-derived mature $\mathrm{T}$ cells, much research has gone into identifying the resident cell subpopulations that constitute this rare facilitating population. Previous studies have shown that the $\mathrm{CD}^{+} / \mathrm{TCR}^{-} \mathrm{FC}$ population shares phenotypic characteristics with $\mathrm{CD} 8 \alpha$ plasmacytoid precursor dendritic cells (p-preDC) and that total FC are heterogeneous in morphology [45]. A comprehensive assessment of FC surface markers using flow cytometric analysis of sorted FC populations by Fugier-Vivier et al. [46] revealed a broad heterogeneity in subpopulations with facilitating potential. The majority of $\mathrm{CD}^{+} / \mathrm{TCR}^{-} \mathrm{FC}$ were positive for $\mathrm{CD}_{11 \mathrm{c}^{+}}(65 \%$ to $70 \%)$ and $\mathrm{B} 220^{+}$(75\% to $88 \%$ ) expression. While only $15 \%$ of the $\mathrm{B} 220^{+}$population was composed of B cells, 55\% co-expressed CD11c (CD11c $\left.{ }^{+} / \mathrm{B}^{2} 20^{+}\right)$, suggestive of a dendritic cell component. Further analysis into this $\mathrm{CD} 11 \mathrm{c}^{+}$dendritic subset revealed that a p-preDC phenotype $\left(\mathrm{CD} 11^{\mathrm{dim}} / \mathrm{B} 220\right.$ $\left.{ }^{+} / \mathrm{CD} 11 \mathrm{~b}^{-}\right)$is the predominant cell type (93\% to $\left.95 \%\right)$ within this $\mathrm{CD}_{11 \mathrm{c}^{+}}$subset (Figure 1 ). The functionality of this p-preDC-like subset of FC has been assessed by transplanting these cells with HSC into ablated murine allogeneic recipients. The co-transplantation of p-preDC rescues allogeneic recipients from radiation aplasia, significantly enhancing alloengraftment and survival compared with ablated recipients that received HSC alone. However, facilitation by this p-preDC component alone was inferior to that observed when the entire FC population was utilized. This observation suggests that the ppre DC subset is necessary, but not sufficient, for HSC facilitation and cannot fully replace the total FC population. Other elegant studies by Taylor et al. indicate that
CD3e expression by $\mathrm{FC}$ and the association of CD3e with TCR $\beta$ chain and a novel $33 \mathrm{kDa}$ protein termed FCp33 is critical for the HSC engraftment enhancing properties of FC [47].

Recent studies have focused on exploring FC and seeking to understand their role in generating tolerance. One such study completed on mice consisted of three groups of purified bone marrow inocula, which contained different subsets of $\mathrm{CD} 8^{+}$cells that were administered to semi-allogeneic recipient mice [48]. The first group was $\alpha \beta-\mathrm{TCR}^{+}$splenic $\mathrm{T}$ cells, the second group was the $\mathrm{CD}^{+} / \mathrm{TCR}^{+}$bone-marrow-derived $\mathrm{T}$ cells, and the third group was the bone-marrow-derived CD8 ${ }^{+} / \mathrm{TCR}^{-}$FC population. The purpose behind this experimental setup was to determine which group of cells would induce GVHD in the recipient mice. There were several important findings that resulted from this study [48]. The first was disproving the common belief that administering donor $\mathrm{CD}^{+} \mathrm{T}$ cells would enhance engraftment and prevent the development of GVHD. This idea is supported by the fact that mice in the first and second groups of the experiment developed lethal GVHD, while mice in the group that received FC failed to develop clinical symptoms or histological evidence of GVHD [48]. Additionally, the researchers reported failure of FC to induce GVHD in mice when the number of FC transplanted was increased from 50,000 to 400,000 , confirming that FC lack GVHD effector activity. Researchers also explored the mechanism behind the lack of GVHD development with transplantation of FC versus transplantation of the $\mathrm{CD}^{+} / \mathrm{TCR}^{+}$bone marrow cells [48]. The results from such studies found an increase in the expression of T-cell-mediated immunosuppression factors. In particular, mice that received HSC with FC showed a significant increase in the transcription of TGF- $\beta$, a cytokine known to be a key player in the induction and development of $\mathrm{T}_{\text {reg. }}$. There was also a considerable increase in the expression of the cyte-associated antigen 4, glucocorticoid-induced TNF receptor and FoxP3 genes, which are associated with $\mathrm{T}_{\text {reg }}$ and suppressor $\mathrm{T}$ cell function. It was concluded that $\mathrm{FC}$ induce the formation of immunoregulatory $\mathrm{T}$ cells in vivo, since the $\mathrm{FC}$ is not a $\mathrm{T}_{\text {reg }}$ and does not express the genes linked to $\mathrm{T}_{\text {reg }}$ [48].

The ability of FC to induce the formation of CD4 ${ }^{+} / \mathrm{CD} 25^{+} \mathrm{T}_{\text {reg }}$ from naive $\mathrm{CD} 4^{+} / \mathrm{CD} 25^{-} \mathrm{T}$ cells, as shown in one recent study, is another proposed mechanism of how FC promote tolerance [49]. CD $4^{+} / \mathrm{CD} 25^{+} \mathrm{T}_{\text {reg }}$ cells have been found to promote bone marrow engraftment and chimerism when transplanted into irradiated recipients [49]. Additionally, $\mathrm{CD} 4^{+} / \mathrm{CD} 25^{+}$cells are thought to prevent the development of GVHD after allogeneic transplantation. Both of these observations are similar to those observed with BMT containing FC. This has lead 
$\mathbf{A}$

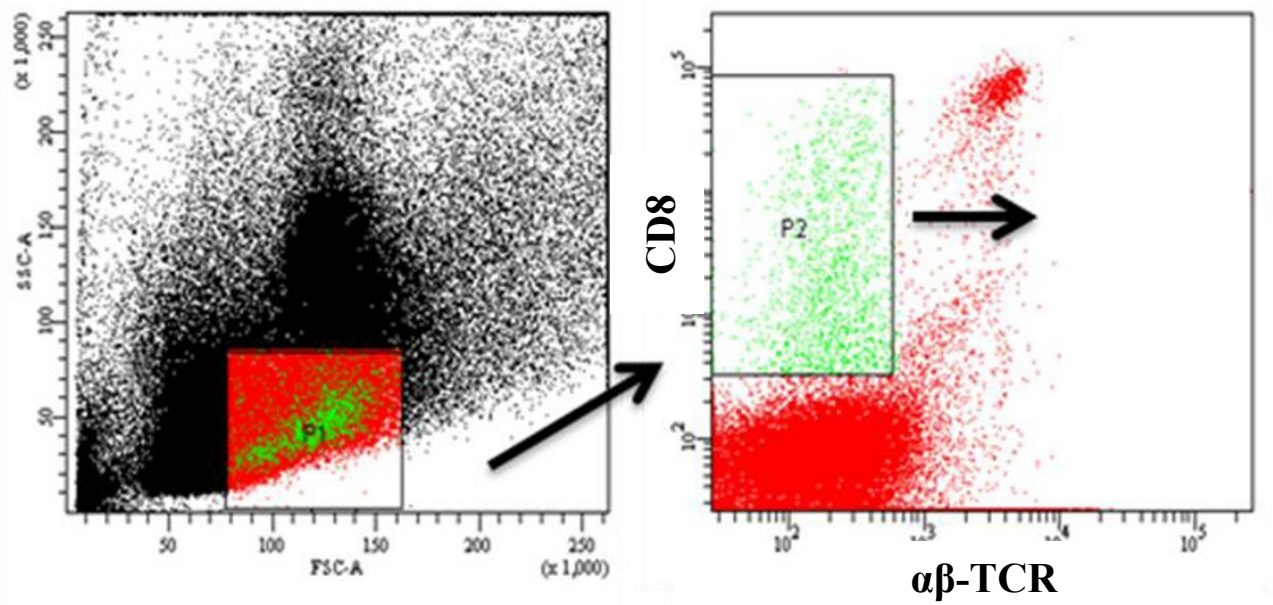

B

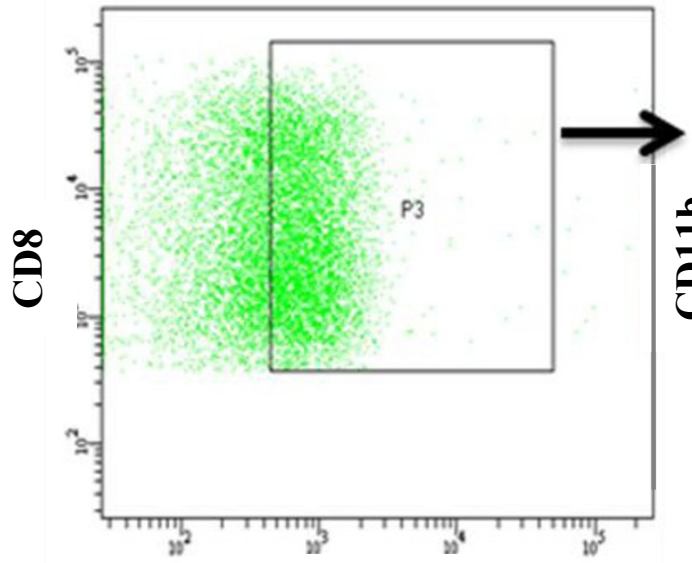

CD11c

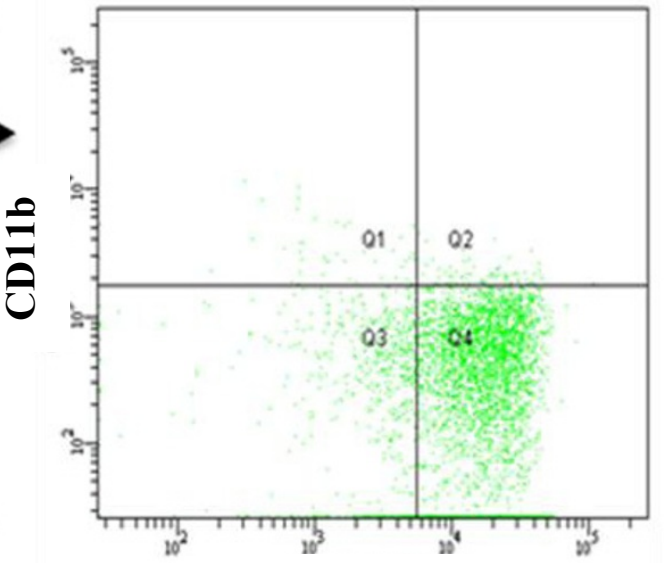

B220

Figure $1 \mathrm{CD}^{+} / \mathrm{TCR}^{-}$facilitating cells. Flow cytometric analysis of bone marrow FC stained with CD8 $\alpha$ phycoerythrin, $\alpha \beta$-TCR fluorescein isothiocyanate, and $\gamma \delta$-TCR fluorescein isothiocyanate mAb. (A) FC comprised approximately $0.4 \%$ (range, $0.04 \%$ to $0.62 \%$ ) of the total bone marrow and less than $1.6 \%$ of cells in the lymphoid gate. (B) The majority of cells in the FC are CD11 $C^{+} / \mathrm{B}^{2} 20^{+} / \mathrm{CD} 11 \mathrm{~b}^{-} \mathrm{p}-\mathrm{preDC}$. FC: facilitating cells; p-preDC: plasmacytoid precursor dendritic cells; TCR: T cell receptor.

researchers to consider an association between FC and $\mathrm{CD} 4^{+} / \mathrm{CD} 25^{+} \mathrm{T}_{\text {reg }}$ in inducing tolerance and preventing GVHD [49].

It was believed that p-preDC were the primary activators of naive $\mathrm{CD} 4^{+} / \mathrm{CD} 25^{-} \mathrm{T}$ cells; however, Taylor et al. have shown that FC possess this function as well [49]. The Taylor study involved mice receiving an allogeneic HSC plus FC transplant and measuring the induction of FoxP $^{+} / \mathrm{CD}^{+} / \mathrm{CD}^{2} 5^{+}$by FC. Three major observations were made by this group that expanded the scientific knowledge of FC. The first was that donor FC were observed in the spleen shortly after transplantation and the induction of donor FoxP $3^{+} / \mathrm{CD}^{+} / \mathrm{CD} 25^{+} \mathrm{T}_{\text {reg }}$ also occurred in the spleen. Since p-preDC activate $\mathrm{T}_{\text {reg }}$ in the spleen, the presence of FC in the spleen prior to activation of $\mathrm{T}_{\text {reg }}$ supports the notion that $\mathrm{FC}$ activate $\mathrm{T}_{\text {reg. }}$. The second was the observation that FC could induce the formation of FoxP3 $3^{+} / \mathrm{CD}^{+} / \mathrm{CD} 25^{+} \mathrm{T}_{\text {reg }}$ from $\mathrm{CD}^{+} / \mathrm{CD} 25^{-} \mathrm{T}$ cells in co-culture. The researchers proposed a mechanism of activation of $\mathrm{FC}$ similar to that of p-preDC, to generate FoxP $3^{+} / \mathrm{CD}^{+} / \mathrm{CD} 25^{+} \mathrm{T}$ cells. However, higher levels of IL4 gene expression were observed with FC-generated $\mathrm{CD} 4^{+} / \mathrm{CD} 25^{+} \mathrm{T}$ cells in comparison with p-preDC-generated $\mathrm{T}$ cells [49]. The last significant observation was that $\mathrm{FC}$ required direct cell-to-cell contact to induce the formation of FoxP3 ${ }^{+} / \mathrm{CD}^{+} / \mathrm{CD} 25^{+} \mathrm{T}_{\text {reg. }}$. Fewer FoxP3 ${ }^{+} / \mathrm{CD} 4^{+} / \mathrm{CD} 25^{+}$cells were produced in the absence of physical contact than when direct contact occurred between the FC and the $\mathrm{CD}^{+} / \mathrm{CD} 25^{-} \mathrm{T}$ cells [49]. Recent studies have suggested that the differentiation of $\mathrm{CD} 4^{+} / \mathrm{CD} 25^{-} \mathrm{T}$ cells into CD4 ${ }^{+} / \mathrm{CD}^{2} 5^{+} \mathrm{T}$ cells requires stimulation from various sources [49]. The B7 receptor is one important aspect of this activation process since studies have demonstrated 
a lower number of $\mathrm{CD} 4^{+} / \mathrm{CD} 25^{+} \mathrm{T}$ cells in mice with a B7 deficiency [49]. CD86 is thought be another important player in assisting $\mathrm{FC}$ to produce $\mathrm{FoxP} 3^{+} / \mathrm{CD} 4$ ${ }^{+} / \mathrm{CD} 25^{+} \mathrm{T}_{\text {reg }}$ because its presence is required for differentiation [49]. More recently, FC have been shown to induce antigen-specific $\mathrm{T}_{\text {reg }}$ in vivo (Figure 2) [50]. Transplantation of FC plus HSC into conditioned allogeneic mouse recipients followed by harvest of CD4 ${ }^{+} / \mathrm{CD} 25^{+} \mathrm{T}_{\text {reg }}$ from the spleen of chimeras (chimeric $\mathrm{T}_{\text {reg }}$ ), and secondary transplantation of the $\mathrm{T}_{\text {reg }}$ with donor HSC plus third-party HSC resulted in engraftment of only the donor HSC, demonstrating antigenspecificity.

In recent years there have been significant advances in understanding the mechanism of FC function, which have provided additional support for the promising potential for FC to be used in the clinic to generate tolerance after HSC transplantation. Data collected from recent studies have helped to distinguish FC from other hematopoietic cells such as p-preDC. However, there are questions that remain to be answered regarding the role of FC in inducing tolerance, preventing GVHD and promoting chimerism following BMT. A phase 2 clinical study approved by the Food and Drug Administration is currently underway to test the use of FC-based HSC transplantation in recipients of living donor renal allografts. Preliminary findings have demonstrated that high levels of donor macrochimerism without GVHD can be established in mismatched recipients conditioned with fludarabine, cyclophosphamide and 200 cGy total body irradiation [51].

\section{Conclusion}

The use of cell-based therapies in the prevention and treatment of GVHD is now being applied in a number of clinical protocols, with promising results. Cell-based

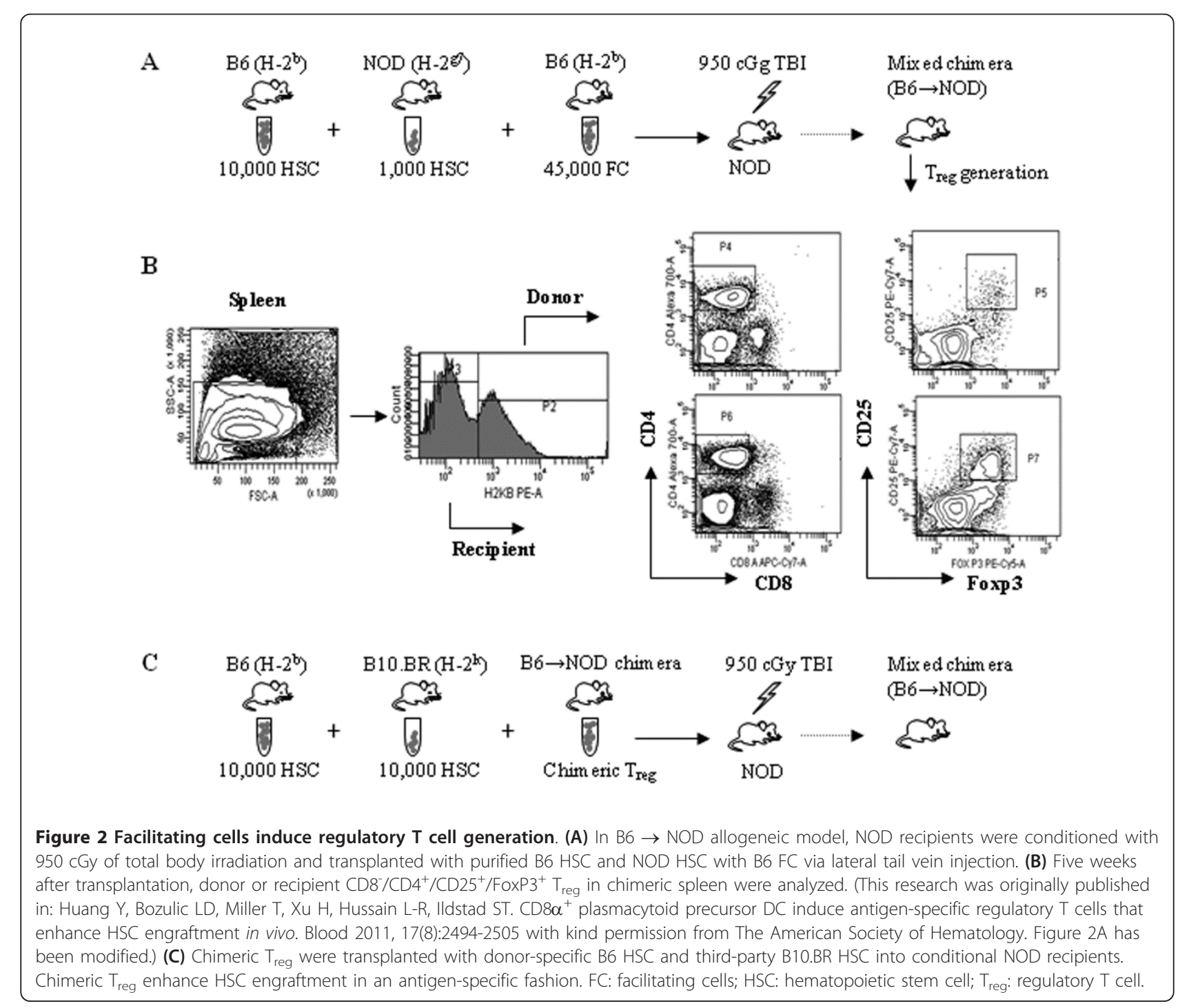


therapies have the potential to promote engraftment, preserve immunocompetence and prevent GVHD, thereby avoiding the toxicity of broad acting nonspecific immunosuppressive agents.

\begin{abstract}
Abbreviations
APC: antigen-presenting cells; BMT: bone marrow transplantation; CCR5: C-C chemokine receptor; CXCR3: CXC chemokine receptor 3; DC: dendritic cells; FC: facilitating cells; FoxP3: forkhead/winged helix transcription factor; GVHD: graft-versus-host disease; GVL: graft-versus-leukemia; HLA: human leukocyte antigen; HSC: hematopoietic stem cell; IL-1: interleukin-1; MHC: major histocompatibility complex; NK: natural killer; p-preDC: plasmacytoid precursor dendritic cells; TCD: T cell depletion; Tcon: conventional donorderived T cells; TCR: T cell receptor; TGF- $\beta$ : transforming growth factor beta; $T_{\text {reg: }}$ regulatory $T$ cell; TNF-a: tumor necrosis factors-a; UCB: umbilical cord blood.
\end{abstract}

\section{Acknowledgements}

The authors thank Dr. Haval Shirwan for a review of the manuscript and helpful comments; Dr. Yujie Wen for extensive reference research; and Carolyn DeLautre for manuscript preparation. This work was supported in part by the following grants: NIH R01 DK069766 and NIH 5RO1 HL063442. This publication was also made possible by Award No.W81XWH-07-1-0185 and W81XWH-09-2-0124 from the U.S. Army Medical Research Acquisition Activity, 820 Chandler Street, Fort Detrick, MD,21702-5014 (Any opinions, findings, and conclusions or recommendations expressed in this material are those of the author(s) and do not necessarily reflect the views of the Office of Army Research); and the Commonwealth of Kentucky Research Challenge Trust Fund.

\section{Author details}

'Comprehensive Transplant Center, Northwestern Memorial Hospital, Chicago, IL, USA. ${ }^{2}$ Institute for Cellular Therapeutics, University of Louisville, Louisville, KY, USA.

\section{Authors' contributions}

$\mathrm{JL}$ : overall preparation and editing of review; YH: studies on role of $\mathrm{T}_{\text {reg }}$ cells in GVHD prevention; HX: studies on role of cyclophosphamide; IG: review of FC mechanism of action; STI: overall editing and preparation of review. All authors have read and approved the final manuscript.

\section{Competing interests}

STI has significant equity interest in Regenerex, LLC, a start-up biotechnology company based on the facilitating cell technology. All other authors have no conflict of interest to declare.

Received: 31 October 2011 Accepted: 15 May 2012

Published: 15 May 2012

\section{References}

1. Shlomchik WD: Graft-versus-host disease. Nat Rev Immunol 2007, 7:340-352.

2. Socie G, Blazar BR: Acute graft-versus-host disease: from the bench to the bedside. Blood 2009, 114:4327-4336.

3. Sakaguchi S: Regulatory T cells: history and perspective. Methods Mol Biol 2011, 707:3-17.

4. Thornton AM, Shevach EM: CD4+CD25+ immunoregulatory T cells suppress polyclonal T cell activation in vitro by inhibiting interleukin 2 production. J Exp Med 1998, 188:287-296.

5. Ermann J, Szanya V, Ford GS, Paragas V, Fathman CG, Lejon K: CD4(+)CD25 (+) T cells facilitate the induction of T cell anergy. J Immunol 2001, 167:4271-4275.

6. Levings MK, Sangregorio R, Roncarolo MG: Human cd25(+)cd4(+) t regulatory cells suppress naive and memory $T$ cell proliferation and can be expanded in vitro without loss of function. J Exp Med 2001, 193:1295-1302.

7. Jonuleit $H$, Schmitt E, Stassen M, Tuettenberg A, Knop J, Enk AH: Identification and functional characterization of human $\mathrm{CD} 4(+) \mathrm{CD} 25(+) \mathrm{T}$ cells with regulatory properties isolated from peripheral blood. J Exp Med 2001, 193:1285-1294.

8. Ukena SN, Velaga S, Geffers R, Grosse J, Baron U, Buchholz S, Stadler M, Bruder D, Ganser A, Franzke A: Human regulatory T cells in allogeneic stem cell transplantation. Blood 2011, 118:e82-92.

9. Miyara M, Sakaguchi S: Human FoxP3(+)CD4(+) regulatory T cells: their knowns and unknowns. Immunol Cell Biol 2011, 89:346-351.

10. Roncarolo MG, Battaglia M: Regulatory T-cell immunotherapy for tolerance to self antigens and alloantigens in humans. Nat Rev Immunol 2007, 7:585-598.

11. Wysocki CA, Jiang Q, Panoskaltsis-Mortari A, Taylor PA, McKinnon KP, Su L, Blazar BR, Serody JS: Critical role for CCR5 in the function of donor CD4 $+\mathrm{CD} 25+$ regulatory $\mathrm{T}$ cells during acute graft-versus-host disease. Blood 2005, 106:3300-3307.

12. Hasegawa H, Inoue A, Kohno M, Lei J, Miyazaki T, Yoshie O, Nose M, Yasukawa M: Therapeutic effect of CXCR3-expressing regulatory T cells on liver, lung and intestinal damages in a murine acute GVHD model. Gene Ther 2008, 15:171-182.

13. Edinger M, Hoffmann P, Ermann J, Drago K, Fathman CG, Strober S, Negrin RS: CD4+CD25+ regulatory T cells preserve graft-versus-tumor activity while inhibiting graft-versus-host disease after bone marrow transplantation. Nat Med 2003, 9:1144-1150.

14. Hoffmann P, Ermann J, Edinger M, Fathman CG, Strober S: Donor-type CD4 $(+) C D 25(+)$ regulatory $T$ cells suppress lethal acute graft-versus-host disease after allogeneic bone marrow transplantation. J Exp Med 2002, 196:389-399.

15. Cohen JL, Trenado A, Vasey D, Klatzmann D, Salomon BL: CD4(+)CD25(+) immunoregulatory $T$ cells: new therapeutics for graft-versus-host disease. J Exp Med 2002, 196:401-406.

16. Di lanni M, Falzetti F, Carotti A, Terenzi A, Castellino F, Bonifacio E, Del PB, Zei T, Ostini Rl, Cecchini D, Aloisi T, Perruccio K, Ruggeri L, Balucani C, Pierini A, Sportoletti P, Aristei C, Falini B, Reisner Y, Velardi A, Aversa F, Martelli MF: Tregs prevent GVHD and promote immune reconstitution in HLA-haploidentical transplantation. Blood 2011, 117:3921-3928.

17. McMurchy AN, Bushell A, Levings MK, Wood KJ: Moving to tolerance: clinical application of T regulatory cells. Semin Immunol 2011, 23:304-313.

18. Trenado A, Charlotte F, Fisson S, Yagello M, Klatzmann D, Salomon BL, Cohen JL: Recipient-type specific CD4+CD25+ regulatory $T$ cells favor immune reconstitution and control graft-versus-host disease while maintaining graft-versus-leukemia. J Clin Invest 2003, 112:1688-1696.

19. Gaidot A, Landau DA, Martin GH, Bonduelle O, Grinberg-Bleyer $Y$, Matheoud D, Gregoire S, Baillou C, Combadiere B, Piaggio E, Cohen JL: Immune reconstitution is preserved in hematopoietic stem cell transplantation coadministered with regulatory T cells for GVHD prevention. Blood 2011, 117:2975-2983.

20. Hippen KL, Merkel SC, Schirm DK, Nelson C, Tennis NC, Riley JL, June CH, Miller JS, Wagner JE, Blazar BR: Generation and large-scale expansion of human inducible regulatory $T$ cells that suppress graft-versus-host disease. Am J Transplant 2011, 11:1148-1157.

21. Brunstein CG, Miller JS, Cao Q, McKenna DH, Hippen KL, Curtsinger J, Defor T, Levine BL, June CH, Rubinstein P, McGlave PB, Blazar BR, Wagner JE: Infusion of ex vivo expanded T regulatory cells in adults transplanted with umbilical cord blood: safety profile and detection kinetics. Blood 2011, 117:1061-1070.

22. Magenau JM, Qin X, Tawara I, Rogers CE, Kitko C, Schlough M, Bickley D, Braun TM, Jang PS, Lowler KP, Jones DM, Choi SW, Reddy P, Mineishi S, Levine JE, Ferrara JL, Paczesny S: Frequency of CD4(+)CD25(hi)FOXP3(+) regulatory $T$ cells has diagnostic and prognostic value as a biomarker for acute graft-versus-host-disease. Biol Blood Marrow Transplant 2010, 16:907-914.

23. Fondi C, Nozzoli $C$, Benemei $S$, Baroni G, Saccardi R, Guidi S, Nicoletti $P$, Bartolozzi B, Pimpinelli N, Santucci M, Bosi A, Massi D: Increase in FOXP3+ regulatory T cells in GVHD skin biopsies is associated with lower disease severity and treatment response. Biol Blood Marrow Transplant 2009, 15:938-947.

24. Zinocker S, Sviland L, Dressel R, Rolstad B: Kinetics of lymphocyte reconstitution after allogeneic bone marrow transplantation: markers of graft-versus-host disease. J Leukoc Biol 2011, 90:177-187.

25. Miura Y, Thoburn CJ, Bright EC, Phelps ML, Shin T, Matsui EC, Matsui WH, Arai $S$, Fuchs EJ, Vogelsang GB, Jones RJ, Hess AD: Association of Foxp3 
regulatory gene expression with graft-versus-host disease. Blood 2004, 104:2187-2193.

26. Zorn E, Kim HT, Lee SJ, Floyd BH, Litsa D, Arumugarajah S, Bellucci R, Alyea EP, Antin JH, Soiffer RJ, Ritz J: Reduced frequency of FOXP3+ CD4 $+\mathrm{CD} 25+$ regulatory $\mathrm{T}$ cells in patients with chronic graft-versus-host disease. Blood 2005, 106:2903-2911.

27. Morishima Y, Sasazuki T, Inoko H, Juji T, Akaza T, Yamamoto K, Ishikawa Y, Kato S, Sao H, Sakamaki H, Kawa K, Hamajima N, Asano S, Kodera Y: The clinical significance of human leukocyte antigen (HLA) allele compatibility in patients receiving a marrow transplant from serologically HLA-A, HLA-B, and HLA-DR matched unrelated donors. Blood 2002, 99:4200-4206.

28. Hahn T, McCarthy PL Jr, Zhang MJ, Wang D, Arora M, Frangoul H, Gale RP, Hale GA, Horan J, Isola L, Maziarz RT, van Rood JJ, Gupta V, Halter J, Reddy V, Tiberghien P, Litzow M, Anasetti C, Pavletic S, Ringden O: Risk factors for acute graft-versus-host disease after human leukocyte antigen-identical sibling transplants for adults with leukemia. J Clin Oncol 2008, 26:5728-5734.

29. Bolwell B, Sobecks R, Pohlman B, Andresen S, Rybicki L, Kuczkowski E, Kalaycio M: A prospective randomized trial comparing cyclosporine and short course methotrexate with cyclosporine and mycophenolate mofetil for GVHD prophylaxis in myeloablative allogeneic bone marrow transplantation. Bone Marrow Transplant 2004, 34:621-625.

30. Cutler C, Li S, Ho VT, Koreth J, Alyea E, Soiffer RJ, Antin JH: Extended follow-up of methotrexate-free immunosuppression using sirolimus and tacrolimus in related and unrelated donor peripheral blood stem cell transplantation. Blood 2007, 109:3108-3114.

31. Ratanatharathorn V, Nash RA, Przepiorka D, Devine SM, Klein JL, Weisdorf D, Fay JW, Nademanee A, Antin JH, Christiansen NP, van der Jagt R, Herzig RH, Litzow MR, Wolff SN, Longo WL, Petersen FB, Karanes C, Avalos B, Storb R, Buell DN, Maher RM, Fitzsimmons WE, Wingard JR: Phase III study comparing methotrexate and tacrolimus (prograf, FK506) with methotrexate and cyclosporine for graft-versus-host disease prophylaxis after HLA-identical sibling bone marrow transplantation. Blood 1998, 92:2303-2314.

32. Colson YL, Wren SM, Schuchert MJ, Patrene KD, Johnson PC, Boggs SS, Ildstad ST: A nonlethal conditioning approach to achieve durable multilineage mixed chimerism and tolerance across major, minor, and hematopoietic histocompatibility barriers. J Immunol 1995, 155:4179-4188.

33. Luznik L, Jalla S, Engstrom LW, lannone R, Fuchs EJ: Durable engraftment of major histocompatibility complex-incompatible cells after nonmyeloablative conditioning with fludarabine, low-dose total body irradiation, and posttransplantation cyclophosphamide. Blood 2001, 98:3456-3464.

34. Luznik L, Engstrom LW, lannone R, Fuchs EJ: Posttransplantation cyclophosphamide facilitates engraftment of major histocompatibility complex-identical allogeneic marrow in mice conditioned with low-dose total body irradiation. Biol Blood Marrow Transplant 2002, 8:131-138.

35. Luznik L, Bolanos-Meade J, Zahurak M, Chen AR, Smith BD, Brodsky R, Huff CA, Borrello I, Matsui W, Powell JD, Kasamon Y, Goodman SN, Hess A, Levitsky HI, Ambinder RF, Jones RJ, Fuchs EJ: High-dose cyclophosphamide as single agent, short-course prophylaxis of graftversus-host disease. Blood 2010, 115:3224-3230.

36. Luznik L, O'Donnell PV, Symons HJ, Chen AR, Leffell MS, Zahurak M, Gooley TA, Piantadosi S, Kaup M, Ambinder RF, Huff CA, Matsui W, BolanosMeade J, Borrello I, Powell JD, Harrington E, Warnock S, Flowers M, Brodsky RA, Sandmaier BM, Storb RF, Jones RJ, Fuchs EJ: HLAhaploidentical bone marrow transplantation for hematologic malignancies using nonmyeloablative conditioning and high-dose, posttransplantation cyclophosphamide. Biol Blood Marrow Transplant 2008, 14:641-650.

37. Li H, Colson YL, Ildstad ST: Mixed allogeneic chimerism achieved by lethal and nonlethal conditioning approaches induces donor-specific tolerance to simultaneous islet allografts. Transplantation 1995, 60:523-529.

38. Mayumi H, Himeno K, Tanaka K, Tokuda N, Fan JL, Nomoto K: Druginduced tolerance to allografts in mice. IX. Establishment of complete chimerism by allogeneic spleen cell transplantation from donors made tolerant to H-2-identical recipients. Transplantation 1986, 42:417-422.

39. Luznik L, Fuchs EJ: High-dose, post-transplantation cyclophosphamide to promote graft-host tolerance after allogeneic hematopoietic stem cell transplantation. Immunol Res 2010, 47:65-77.
40. Luznik L, Jones RJ, Fuchs EJ: High-dose cyclophosphamide for graftversus-host disease prevention. Curr Opin Hematol 2010, 17:493-499.

41. Nomoto K, Eto M, Yanaga K, Nishimura Y, Maeda T, Nomoto K: Interference with cyclophosphamide-induced skin allograft tolerance by cyclosporin A. J Immunol 1992, 149:2668-2674.

42. Mielcarek M, Martin PJ, Leisenring W, Flowers ME, Maloney DG, Sandmaier BM, Maris MB, Storb R: Graft-versus-host disease after nonmyeloablative versus conventional hematopoietic stem cell transplantation. Blood 2003, 102:756-762.

43. Leventhal J, Abecassis M, Miller J, Gallon L, Ravindra K, Tollerud D, King B, Elliott MJ, Herzig G, Herzig R, Ildstad ST: Chimerism and tolerance without GVHD or engraftment syndrome in HLA-mismatched combined kidney and hematopoietic stem cell transplantation. Sci Transl Med 2012, 4:1-10.

44. Kaufman CL, Colson YL, Wren SM, Watkins SL, Simmons RL, Idstad ST: Phenotypic characterization of a novel bone-marrow derived cell that facilitates engraftment of allogeneic bone marrow stem cells. Blood 1994, 84:2436-2446.

45. Gandy KL, Domen J, Aguila HL, Weissman IL: $\mathrm{CD}^{+} \mathrm{TCR}^{+}$and $\mathrm{CD} 8^{+} \mathrm{TCR}$ cells in whole bone marrow facilitate the engraftment of hematopoietic stem cells across allogeneic barriers. Immunity 1999, 11:579-590.

46. Fugier-Vivier I, Rezzoug F, Huang Y, Graul-Layman AJ, Schanie CL, Xu H, Chilton PM, Ildstad ST: Plasmacytoid precursor dendritic cells facilitate allogeneic hematopoietic stem cell engraftment. J Exp Med 2005, 201:373-383.

47. Taylor KN, Shinde P, Colson YL: Reconstitution of allogeneic hemopoietic stem cells: the essential role of FCR\{gamma\} and the TCR beta-chainFCp33 complex. J Immunol 2006, 177:1444-1450.

48. Colson YL, Christopher K, Glickman J, Taylor KN, Wright R, Perkins DL: Absence of clinical GVHD and the in vivo induction of regulatory T cells following facilitating cell transplantation. Blood 2004, 104:3829-3835.

49. Taylor KN, Shinde-Patil VR, Cohick E, Colson YL: Induction of FoxP3+CD4 $+25+$ regulatory $T$ cells following hemopoietic stem cell transplantation: role of bone marrow-derived facilitating cells. J Immunol 2007, 179:2153-2162.

50. Huang Y, Bozulic LD, Miller T, Xu H, Hussain LR, Ildstad ST: CD8a ${ }^{+}$ plasmacytoid precursor DC induce antigen-specific regulatory $\mathrm{T}$ cells that enhance HSC engraftment in vivo. Blood 2011, 117:2494-2505.

51. Leventhal J, Gallon L, Miller J, Mehta J, Zakarija A, Abecassis M, Tollerud D, Herzig R, Ravindra K, Ildstad ST: Induction of donor specific tolerance in recipients of HLA disparate living donor kidney allografts by donor stem cell infusion [abstract]. Am J Transplant 2011, 11:76, [Meeting abstract 150].

\section{Pre-publication history}

The pre-publication history for this paper can be accessed here: http://www.biomedcentral.com/1741-7015/10/48/prepub

doi:10.1186/1741-7015-10-48

Cite this article as: Leventhal et al: Novel regulatory therapies for prevention of Graft-versus-host disease. BMC Medicine 2012 10:48.

\section{Submit your next manuscript to BioMed Central and take full advantage of:}

- Convenient online submission

- Thorough peer review

- No space constraints or color figure charges

- Immediate publication on acceptance

- Inclusion in PubMed, CAS, Scopus and Google Scholar

- Research which is freely available for redistribution

Submit your manuscript at www.biomedcentral.com/submit
C Biomed Central 